\title{
Studi Etnobotani Dan Etnofarmakologi Umbi Binahong (Anredera cordifolia (Ten) Steenis)
}

\author{
Siti Rofida \\ Program Studi Farmasi Fakultas Ilmu Kesehatan Universitas Muhammadiyah \\ Malang \\ Alamat Korespondensi: ro_fida@yahoo.co.id
}

\begin{abstract}
ABSTRAK
Pengetahuan penggunaan tumbuhan sebagai obat tradisional hanyalah berdasarkan empiris. Perubahan pola pengobatan modern ke pengobatan tradisional, menyebabkan kebutuhan terhadap obat yang berasal dari bahan alam menjadi meningkat. Bahan alam yang digunakan sebagai obat sebaiknya berpegangan kepada pedoman bahwa bahan obat tersebut tidak menimbulkan keracunan baik akut maupun kronis dan terbukti bisa menyembuhkan penyakit atau berkhasiat sebagai obat serta dapat diperoleh secara kontinu. Secara empiris masyarakat kota Malang menggunakan umbi binahong (Anredera cordifolia (Ten) Steenis) untuk mengobati nyeri pada gigi yang disertai dengan pembengkakan yang keluar nanah, gastritis akut, nyeri kepala, panas dalam yang disertai sariawan, mengobati luka bekas operasi, mengurangi nyeri setelah operasi dan lain-lain. Ciri-ciri morfologi umbi binahong berbentuk silindris dengan tekstur permukaan yang tidak rata, panjangnya antara $4-7 \mathrm{~cm}$ dengan diameter 0,5 - $2 \mathrm{~cm}$ dan berdaging lunak. Secara anatomis tampakjaringan dasar (parenkim), berkas pengangkutan (xylem dan floem) dan benda ergastrik berupa amilum. Tumbuhan ini mudah tumbuh di dataran rendah maupun dataran tinggi.
\end{abstract}

Kata kunci: obat tradisional, umbi, Anredera cordifolia(Tenn)Steenis,.

\section{Latar Belakang}

Penggunaan tanaman sebagai obat, bahan makanan, bumbu, maupun sebagai kosmetika telah dikenal sejak zaman kuno. Bukti penggunaan tumbuhan sebagai obat tertulis dalam berbagai dokumen seperti Huang Ti Nei Ching Su Wen (The Yellow Emperor's Medicine), Papyrus Smith, Papyrus Ebers, Ayurveda. Bukti penggunaan tumbuhan obat di Indonesia tertulis dalam naskah lama pada laun lontar Husodo (Jawa), Usada (Bali), Lontarak pabbura (Sulawesi Selatan), dan dokumen lain seperti Serat Primbon Jampi, Serat Racikan Boreh Wulang Dalem dan juga pada relief yang terdapat pada candi Borobudur yang menggambarkan orang sedang meracik obat (jamu) dengan tumbuhan sebagai bahan bakunya. Pengetahuan penggunaan tumbuhan tersebut sebagai bahan obat tradisional disampaikan dari orang ke orang, dari keluarga ke keluarga, suku ke suku, generasi ke generasi. Kemajuan peradapan modern, yang ditandai dengan perkembangan ilmu pengetahuan dan teknologi, mengakibatkan pengobatan berkecenderungan menggunakan produk artificial. Penggunaan dan pemanfaatan tanaman sebagai obat sempat mengalami kemunduran beberapa saat, kecuali untuk penggunaan sebagai bumbu dan rempahrempah serta kosmetika. Akan tetapi situasi ini berubah secara global dalam 20 tahun terakhir yang mengarah ke perubahan penggunaan bahan alam (Wiryowidagdo, 2008). Perubahan pola pengobatan tersebut menyebabkan kebutuhan bahan alam sebagai obat menjadi meningkat, baik macamnya dan jumlahnya.

Sebagian besar bahan alam yang digunakan sebagai obat tradisional belum dipelajari khasiatnya secara ilmiah. Khasiat tersebut pada dasarnya disebabkan karena 
ada zat-zat kandungan tertentu dalam bentuk senyawa alkaloida, glikosida, minyak atsiri dan lain-lain. Untuk mengetahui suatu bahan obat tradisioanal berkhasiat, harus ditunjukkan adanya zat - zat berkhasiat dalam bahan tersebut, baik secara kimiawi maupun secara biologi. Selain secara kualitatif, zat - zat kandungan berkhasiat tersebut harus dapat ditetapkan kadarnya secara kuantitatif (Sutarjadi,dkk.,1980)

Semua bahan alam yang digunakan sebagai obat sebaiknya berpegangan kepada pedoman bahwa bahan obat tersebut tidak menimbulkan keracunan baik akut maupun kronis dan bahan obat tersebut terbukti bisa menyembuhkan penyakit atau berkhasiat sebagai obat. Hal ini bertujuan untuk melindungi masyarakat dan memberikan informasi tentang penggunaan obat tradisional yang didukung data ilmiah yang meliputi khasiat, keamanan dan tanaman tersebut harus dapat diperoleh secara kontinu (Sutarjadi,1988).

Guna mendukung terpenuhi persyaratan diatas, perlu dilakukan survey dan penelitian yang melibatkan banyak bidang ilmu yang meliputi :

1. Inventaris tumbuhan obat berdasarkan studi etnobotani dan etnofarmakologi, harus dapat dipastikan penggunaan bahan-bahan atau ramuannya oleh penduduk setempat. Komponen ramuan obat tradisional dapat diidentifikasi dari segi botani, harus dapat diketahui sumber tumbuhan sampai pada nama jenis, nama varitas.

2. Penelitian farmakognosi dan fitokimia, setelah diperoleh kepastian sumber botani simplisia, dilanjutkan dengan mempelajari ciri-ciri makroskopis dan mikroskopis, didukung penelitian fitokimia guna mendukung data persyaratan dan spesifikasi yang diperlukan untuk uji keaslian dan kemurnian bahan /simplisia. Letak tumbuh dari tumbuhan dapat mempengaruhi zat kimia yang terkandung didalamnya.

3. Penelitian farmakologi dan toksikologi, untuk memastikan khasiat simplisia bahan tumbuhan obat dengan menggunakan percobaan organ terpisah atau hewan percobaan yang sesuai. Disamping itu juga perlu dilakukan uji toksisitas kronik maupun subkronik guna mengetahui kemungkinan ada efek yang merugikan. Hasil penelitian berguna untuk penentuan dosis terapetik yang aman ataupun untuk peringatan bagi pemakaianya.

4. Uji manfaat bahan tumbuhan obat (Uji Klinik), perlu dilakukan uji manfaat pada penderita untuk membuktikan khasiat maupun kemungkinan adanya efek samping pada manusia.

Salah satu tanaman yang sering digunakan adalah umbi Anredera cordifolia (Ten.) Steenis atau yang dikenal oleh masyarakat dengan binahong. Di Indonesia tanaman ini belum banyak dikenal, namun masyarakat sudah memanfaatkan sediaan jadi dari binahong yang berasal dari Cina untuk membantu proses penyembuhan beragam penyakit. Sebagian masyarakat mengganggap bahwa binahong yang asli adalah binahong yang berasal dari Cina, sedangkan tanaman binahong yang tumbuh di Indonesia adalah binahong yang palsu. Harga binahong yang berasal dari Cina tersebut relatif mahal dan tidak banyak apotek maupun toko obat yang menyediakan obat tersebut. Guna memenuhi kebutuhan obat tradisional, khususnya yaitu binahong, maka perlu dilakukan penelitian untuk membuktikan bahwa binahong yang tumbuh di Indonesia juga mempunyai khasiat yang sama dengan binahong yang tumbuh di Cina.

Untuk itu perlu dilakukan penelitian pendahuluan yaitu studi etnobotani dan etnofarmakologi. Kajian ilmu botani mengenai pemanfaatan tumbuhan dalam keperluan sehari-hari dan adat suku bangsa dikenal dengan etnobotani. Studi etnobotani tidak hanya mengenai data botani taksonomis, namun juga meliputi pengetahuan botani yang bersifat kedaerahan, berupa tinjauan yang mempelajari hubungan timbal balik antara manusia dengan tanaman, serta menyangkut pemanfaatan tanaman tersebut lebih diutamakan untuk kepentingan budaya dan kelestarian sumber daya alam (Dharmono,2007).

Kajian botani meliputi bentuk dan susunan luar dan dalam dari tumbuhan secara makroskopis dan mikroskopis. Identifikasi ini bertujuan untuk mengungkapkan atau menetapkan identitas suatu tumbuhan, sehingga mencegah terjadinya kekeliruan dalam penggunaan tumbuhan tersebut sebagai obat tradisional. Tumbuhan yang ada dibumi sangat banyak jumlah maupun ragamnya. Sehingga diperlukan identifikasi 
tumbuhan dan penggolongan atau klasifikasi dalam suatu sistem yang memberikan gambaran hubungan kekerabatan dalam sejarah perkembangan antara tumbuhan yang satu dengan lainnya. (Tjitrosoepomo,2005). Kajian Etnofarmakologi meliputi penggunaan tanaman sebagai obat tradisional secara empiris di suatu daerah tertentu.

\section{Tujuan Penelitian}

Memberikan data mengenai budaya pengobatan masyarakat di Kota Malang yang menggunakan umbi binahong dalam mengobati penyakit. Selain itu juga diperoleh data tentang ciri-ciri makroskopis dan mikroskopis sehingga keaslian dan kemurnian simplisia umbi Anredera cordifolia (Ten.) Steenis dapat terjamin. Serta data tentang habitat yang tepat untuk tumbuh dari tanaman Anredera cordifolia (Ten.) Steenis sehingga mendukung keberlangsungan hidup dari tanaman tersebut. Data ini menjadi data pendahuluan untuk pengembangan umbi Anredera cordifolia (Ten.) Steenis sebagai obat tradisional.

\section{Metode Penelitian \\ Desain Penelitian}

Desain penelitian merupakan penelitian deskriptif melalui pendekatan observasional laboratoris. Langkah pertama dari penelitian yaitu melakukan identifikasi dan mendeskripsikan penggunaan umbi Anredera cordifolia (Ten.) Steenis di masyarakat kota malang. Langkah kedua melakukan pengamatan terhadap habitat tempat tumbuhnya serta pengamatan morfologi dan anatomi umbi Anredera cordifolia (Ten.) Steenis.

\section{b. Populasi dan Sampel}

Populasi dari penelitian ini adalah tanaman Anredera cordifolia (Ten.) Steenis, yang tumbuh didaerah kota Malang. Sampel yang digunakan adalah umbi yang diambil dari tanaman Anredera cordifolia (Ten.) Steenis yang tumbuh di 3 lokasi yang berbeda yaitu, daerah dataran tinggi (pegunungan), daerah dataran rendah dan daerah pesisir pantai di kota malang.

\section{Hasil dan Pembahasan Studi Etnofarmakologi} Dari hasil wawancara terhadap masyarakat kota Malang yang tinggal didaerah pegunungan (dataran tinggi), dataran rendah dan pesisir pantai yang menggunakan umbi binahong, dapat disimpulkan bahwa pada umumnya mereka menggunakan umbi binahong (Anredera cordifolia (Ten) Steenis) untuk mengobati nyeri pada gigi yang disertai dengan pembengkakan yang keluar nanah, gastritis akut, nyeri kepala, panas dalam yang disertai sariawan, mengobati luka bekas operasi, mengurangi nyeri setelah operasi, mengurangi peradangan setelah operasi, ambeien (wasir), asam urat, rheumatik, menormalkan kadar kolesterol dalam darah, vertigo, tifus, radang tenggorokan, migraine. Masyarakat pada umumnya mendapatkan informasi bahwa tanaman binahong berkhasiat sebagai obat dari pengalaman orang-orang yang telah lebih awal menggunakan umbi binahong.

Selain umbi, bagian dari tanaman binahong yang sering juga digunakan adalah daunnya. Masyarakat yang tinggal didaerah pegunungan dan dataran rendah lebih banyak menanam tanaman binahong di halaman rumah dibandingkan masyarakat di daerah pesisir pantai. Masyarakat pesisir pantai lebih mempercayai binahong yang berasal dari Cina.

Selain untuk mengobati gejala penyakit, masyarakat mengkonsumsi binahong untuk memelihara kesehatan. Cara minum bervariasi antara sehari, tiga hari dan seminggu sekali. Umbi yang digunakan adalah umbi yang sudah mempunyai diameter $1-2 \mathrm{~cm}$.

Telah disebutkan sebelumnya bahwa tanaman mempunyai khasiat untuk pengobatan, pada dasarnya disebabkan karena ada zat-zat kandungan tertentu dalam bentuk senyawa alkaloida, glikosida, minyak atsiri dan lain-lain. Senyawa kimia tersebut tersimpan pada organ tanaman yaitu daun, umbi, batang dan akar dengan kadar yang berbeda-beda. Dari hasil penelitian sebelumnya disebutkan bahwa pada daun binahong terkandung senyawa saponin, triterpenoid, flavonoid dan minyak atsiri. Flavonoid dapat berperan langsung sebagai antibiotic dengan menggangu fungsi dari mikroorganisme seperti bakteri dan virus. Senyawa terpenoid adalah senyawa hidrokarbon isometric membantu tubuh dalam proses sintesa organik dan pemulihan 
sel-sel tubuh. Sedangkan saponin dapat menurunkan kolesterol, mempunyai sifat sebagai antioksidan, antivirus dan anti karsinogenik.

\section{Studi Etnobotani}

Pada pengamatan ciri morfologinya, diperoleh data yaitu bahwa umbi binahong (Anredera cordifolia (Ten) Steenis) berbentuk silindris dengan tekstur permukaan yang tidak rata, ukuran panjangnya bervariasi antara $4-7 \mathrm{~cm}$ dengan diameter $0,5-2 \mathrm{~cm}$ dan berdaging lunak. Tidak ada perbedaan ukuran dari umbi yang diperoleh dari daerah pegunungan, dataran rendah dan pesisir pantai. Tumbuhan ini mudah tumbuh di dataran rendah maupun dataran tinggi. Banyak ditanam di dalam pot sebagai tanaman hias dan obat. cukup mudah, hal ini dapat dilihat bahwa tanaman ini dapat hidup didaerah dataran rendah dan daerah dataran tinggi. Namun dari hasil pengamatan dan wawancara, tanaman binahong yang ditanam oleh masyarakat tumbuh seperti tanaman liar, yang berkembang dengan pesat. Tanaman binahong merupakan tanaman yang menjalar, sehingga terkadang masyarakat memotong untuk membatasi pertumbuhannya, karena dapat mengganggu pertumbuhan tanaman disekitarnya.

Perbanyakan tanaman binahong dapat dilakukan melalui dua cara yaitu, secara vegetatif dan generatif dengan menggunakan umbi dan biji. Perbanyakan secara vegetatif yaitu dari umbi dengan cara mencabut atau memisahkan umbi dari pohon induk, dipilih umbi yang telah cukup tua.

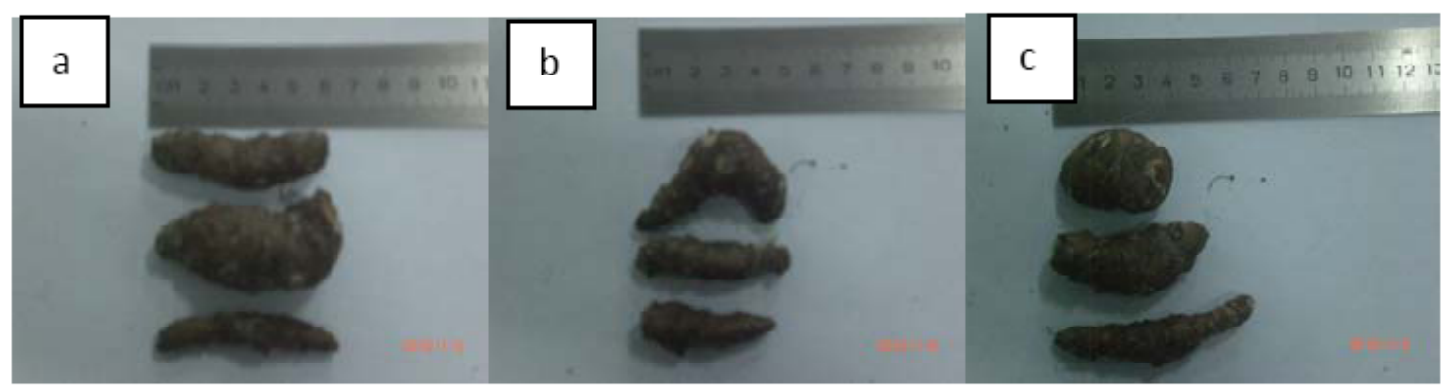

Gambar 2. Umbi binahong (a. Pegunungan, b. dataran rendah, c. pesisir pantai.)

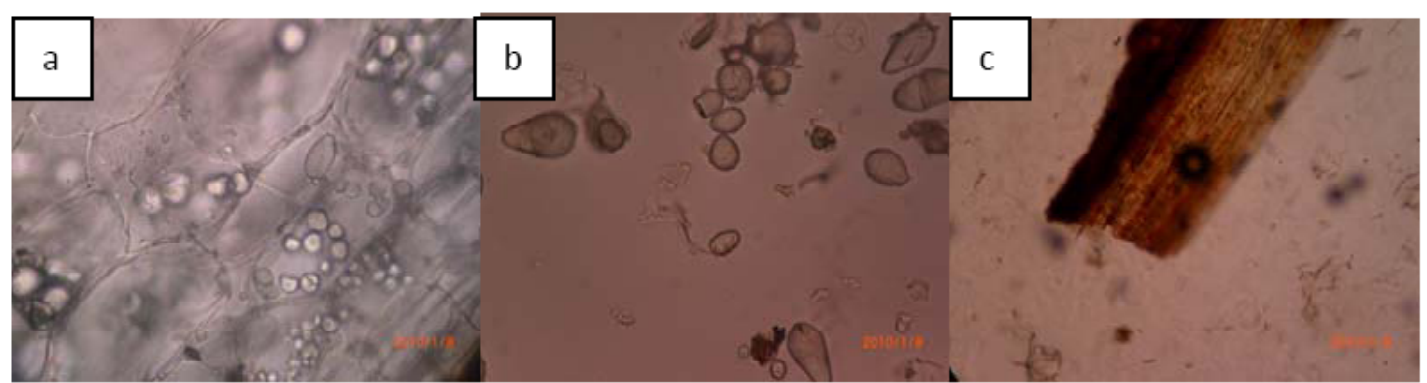

Gambar 3. Pengamatan mikroskopis (a. parenkim, b. amilum, c. berkas pengangkutan)

Pada pengamatan mikroskopis dari irisan melintang dan serbuk umbi binahong, jaringan yang tampak adalah jaringan dasar (parenkim), berkas pengangkutan (xylem dan floem) dan benda ergastrik berupa amilum. Tidak ada perbedaan antara umbi yang diperoleh dari daerah pegunungan, daerah dataran rendah dan pesisir pantai. Jaringan parenkim berbentuk polyhedral. Amilum berbentuk oval dengan satu sisi ujungnya lebih lebar, ada juga yang berbentuk rompah, hilus berbetuk rekahan terletak pada bagian ujung yang lebar.

Untuk mendapatkan umbi binahong
Umbi ditanam pada media tanah yang telah dicampur pupuk kandang dengan perbandingan $1: 1$. Umbi yang telah ditanam sebaiknya diberi naungan sampai $50 \%$. Perbanyakan secara generatif yaitu melalui biji dapat dilakukan apabila bijinya telah matang. Biji yang disemaikan pada pembibitan setelah memiliki 4 - 6 daun dengan umur tanaman kurang lebih 1 bulan sudah dapat dipindahkan ke lapangan. Perbanyakan tanaman, umumnya lebih banyak menggunakan cara vegetatif dengan menggunakan umbi karena lebih cepat tumbuh dan sifatnya sama dengan induknya. 
Binahong tumbuh baik pada tempat teduh dan agak lembab.

\section{Kesimpulan}

Tanaman binahong (Anredera cordifolia (Ten) Steenis) merupakan salah satu tanaman yang pontensial untuk digali mengenai data informasi tanaman untuk dikembangkan menjadi fitofarmaka. Dari hasil wawancara terhadap masyarakat di kota Malang, umbi binahong biasa digunakan untuk mengobati nyeri pada gigi yang disertai dengan pembengkakan yang keluar nanah, gastritis akut, nyeri kepala, panas dalam yang disertai sariawan, mengobati luka bekas operasi, mengurangi nyeri setelah operasi, mengurangi peradangan setelah operasi, ambeien (wasir), asam urat, rheumatik, menormalkan kadar kolesterol dalam darah, vertigo, tifus, radang tenggorokan, migraine. Selain untuk mengobati, ternyata masyrakat juga menggunakan untuk menjaga vitalitas tubuh.

Pada pengamatan ciri morfologinya diperoleh data yaitu bahwa umbi binahong (Anredera cordifolia (Ten) Steenis) berbentuk silindris dengan tekstur permukaan yang tidak rata, ukuran panjangnya bervariasi antara $4-7 \mathrm{~cm}$ dengan diameter $0,5-2 \mathrm{~cm}$ dan berdaging lunak. Tumbuhan ini mudah tumbuh di dataran rendah maupun dataran tinggi. Pada pengamatan mikroskopis dari irisan melintang dan serbuk umbi binahong, jaringan yang tampak adalah jaringan dasar (parenkim), berkas pengangkutan (xylem dan floem) dan benda ergastrik berupa amilum.

Pengembangan suatu tanaman menjadi tanaman yang berkhasiat sebagai obat, selain terbukti berkhasiat melalui serangkaian penelitian, tanaman tersebut juga diharapkan mudah didapatkan dan keberlangsungan tanaman juga harus diperhatikan. Perbanyakan tanaman binahong dapat dilakukan melalui dua cara yaitu dilakukan secara vegetatif dan generatif dengan menggunakan umbi dan biji. Namun perbanyakan cara vegetatif dari umbi merupakan cara yang yang paling banyak digunakan karena lebih cepat tumbuh dan sifatnya sama dengan induknya. Binahong tumbuh baik pada tempat teduh dan agak lembab.

\section{Daftar Pustaka}

Dharmono. 2007. Kajian Etnobotani Tumbuhan Jalukap (Centella asiatica .L) Di Suku Dayak Bukit Desa Haratai 1 Loksado. Jurnal Bioscientiae Volume 4, Nomor 2, halaman 71-78. Universitas Lambung Mangkurat. Banjarmasin.

Gana S, Asep. Marlia Singgih. Haryanto Dh. 2008. Prospek Tumbuhan Indonesia Dalam Kesehatan Dan Permasalahannya. Medisina, Ed.4, Vol.II. PT.ISFI Penerbitan. Jakarta.

Gembong Tjitrosoepomo. 2005. Taksonomi Umum. Gadjah Mada University Press. Yogyakarta.

Gembong Tjitrosoepomo. 2005. Morfologi Tumbuhan. Gadjah Mada University Press. Yogyakarta.

Martin, Gary J. 2004. Ethnobotany, People and Plants Conservation Manual. Earthscan.

Manoi, Feri. 2009. Binahong (Anredera cordifolia) Sebagai Obat. Warta Penelitian Dan Pengembangan Tanaman Industri. Volume 5, Nomor 1.

Mulyani E.S, Sri. Anatomi Tumbuhan. Kanisius. Yogyakarta.

Rachmawaty. 2008. Studi Makroskopis Mikroskopis dan Skrining Fitokimia Daun Anredera cordifolia (Ten) Steenis. Universitas Airlangga. Surabaya.

Sutarjadi. 1988. Peran Serta Indonesia Dalam Pengembangan Standarisasi 'Asean Herbal Medicine' dan Usaha Pemanfaatannya Untuk Pelayanan Kesehatan Primer. Simposium Penelitian Tumbuhan Obat VI. Jakarta.

Sutrjadi. Wahjo Djatmiko. Gunawan Indrayanto. 1980. Penelitian Fitokimia Obat Tradisional dan Tumbuhan Obat Untuk Penemuan Obat-obatan Baru, Seminar 
Pengembangan Obat Tradisional. Seminar Pengembangan Obat Tradisional. Surabaya.

Sutarjadi. 1978. Penggunaan Obat Tradisional Ditinjau Dari Segi Farmasi. Pekan Ekspor Tanaman Obat Tradisional. Surakarta.

Sutrian,Yayan. 2004. Pengantar Anatomi Tumbuh-Tumbuhan. Rineka Cipta. Jakarta.

Wiryowidagdo, Sumali. 2008. Kimia Dan Farmakologi Bahan Alam. Buku Kedokteran EGC, Jakarta. 